\title{
ОСОБЕННОСТИ ОБУЧЕНИЯ ИГРЕ НА САКСОФОНЕ:
} ЕВРОПЕЙСКИЙ ОПЫТ

\section{FEATURES OF SAXOPHONE LEARNING: THE EUROPEAN EXPERIENCE}

Jiang Wenjie

Summary: The article is devoted to the European experience of saxophone learning on the example of some European countries. The relevance of the research topic is due to the fact that in the general system of music education, teaching the saxophone has its own characteristics, which are most pronounced in national models of pay learning for this instrument. The saxophone specificity as a musical instrument lies in its relatively recent recognition and inclusion in the musical educational program of classical musical educational institutions. The purpose of the article is to summarize the characteristics of existing models of learning to play the saxophone (in European countries' example). Objectives of the article are: to consider the instrument' history, to identify the main characteristics of various national models of learning the saxophone. The methodology of the article is based on a systematic approach and includes the methods of the general scientific group (analysis, synthesis, deduction, induction), as well as special methods: content analysis of scientific literature on the research topic; historical analysis method, as well as descriptive analysis. The author of the article concludes that in modern European musical pedagogical practice, there are three main models of learning the saxophone, including the e- learning format. This experience must be taken into account in the development of Russian training programs for playing the saxophone.

Keywords: musical pedagogy, jazz, saxophone, European teaching models, music theory.
A ктуальность темы исследования обусловлена тем, что в отечественной музыкальной практике обучению игре на саксофоне основное внимание уделяется классическим педагогическим моделям, разработанным русскими педагогами. В то же время, для совершенствования конкурентоспособности российских саксофонистов на мировой музыкальной арене необходимо учитывать опыт европейских национальных музыкальных учебных заведений. Историография исследуемой темы достаточно обширна. Общим вопросам обучения игре на саксофоне посвящены работы таких авторов, как Л.А. Реббек [10], Р. Инграм и Дж. Кросс [8], Х. Мартин и К. Вайтерс [9].

Особенности некоторых национальных школ обучения игре на саксофоне освещены в работах таких авторов, как Л.Б. Друтин [1] и А.М. Понькина [2,3].

\author{
Цзян Вэньцзэ \\ ассистент-стажер, ФГБОУ ВО «Российская академия \\ музыки имени Гнесиных» \\ 68789265@q9.com
}

Аннотация: Статья посвящена европейскому опыту обучения игры на саксофоне на примере европейских стран. Актуальность темы исследования обусловлена тем, что в общей системе музыкального образования обучение на саксофоне имеет свои особенности, которые наиболее ярко выражены в национальных моделях обучения игре на данном инструменте. Специфика саксофона как музыкального инструмента заключается в его относительно недавнем признании и включении в музыкальную образовательную программу классических музыкальных образовательных учреждений. Цель статьи заключается в обобщении характеристик существующих моделей обучения игре на саксофоне (на примере европейских стран). Задачи статьи: рассмотреть историю возникновения инструмента, выявить основные характеристики различных национальных моделей обучения игре на саксофоне. Методология статьи основана на системном подходе и включает в себя методы общенаучной группы (анализ, синтез, дедукция, индукция), а также специальные методы: контент-анализ научной литературы по теме исследования; метод исторического анализа, а также метод описательного анализа. Автор статьи приходит к выводу о том, что в современной европейской музыкальной педагогической практике существует три основных модели обучения игре на саксофоне, включая формат онлайн-обучения. Данный опыт необходимо учитывать в разработке российских программ обучения игре на саксофоне.

Ключевые слова: музыкальная педагогика, джаз, саксофон, европейские модели обучения, теория музыки.

Тем не менее, в российской музыкальной педагогике наблюдается некоторая нехватка работ, посвященных осмыслению европейского опыта обучения игре на саксофоне, что обусловлено, на наш взгляд, недостаточной степенью признания данного инструмента с точки зрения классических параметров музыкальных учебных заведений в России. Тем не менее, в европейских странах саксофон классифицируется как один из самых популярных деревянных духовых инструментов [6, с.47].

Более того, сам инструмент был изначально изобретен в Европе, в Бельгии, музыкантом и производителем инструментов А. Саксом. Его музыкальное творение стало революцией в музыкальной индустрии, что, в свою очередь, способствовало формированию новых музыкальных жанров.

Новый инструмент, созданный А. Саксом, практи- 
чески сразу начал завоевывать признание публики и привлекать внимание известных людей, вовлеченных в музыкальную индустрию. В частности, интерес к новому инструменту и его возможностям проявил Франсуа Антуан Хабенек, дирижер оркестра Парижской оперы [8, c.22]. В 1841 году, на промышленной выставке в Брюсселе А. Сакс представил публике свое самое важное изобретение: духовой инструмент, состоящий из одного тростника, конической трубки и пальцевых клавиш, которое стало известно как саксофон и было запатентовано в 1846 году. После переезда в Париж, на то момент бывший музыкальной столицей Европы, А. Сакс сформировал собственный мастер-класс по обучению игре на этом инструменте [9, с.102].

Именно в Париже саксофоном заинтересовался знаменитый музыкальный критик и композитор Г. Берлиоз, который был так вдохновлен творчеством А. Сакса, что написал весьма позитивный обзор саксофона с точки зрения его музыкальных характеристик и возможностей. Вскоре А. Сакс начал выпускать саксофон разных размеров (классика, альт, тенор-саксофон), а затем инструмент стал использоваться в классических музыкальных постановках в Париже [6, с.45].

Интересно, что в европейских странах саксофон был особенно популярен среди военных оркестров. Однажды А. Сакс организовал «боевой конкурс» между двумя разными военными оркестрами, один из которых играл на саксофоне, а другой - на традиционных инструментах французской пехотной роты. Группа с саксофоном выиграла конкурс, и военные включили саксофон в свои музыкальные группы. Несмотря на большой успех, А. Сакс постоянно переживал трудности в бизнесе и трижды подвергался банкротству. Интересно, что ему удалось избежать четвертого банкротства с помощью императора Наполеона III, одного из главных поклонников саксофона $[8$, с.76].

Ко времени смерти А. Сакса (7 февраля 1894 года) саксофон стал очень успешным в ансамблевой музыке, но так и не был признан инструментом для классической музыки, на что всегда надеялся А. Сакс. Однако в XX веке изобретение А. Сакса революционизировало мир музыки и стало проводником одного из самых популярных жанров, когда-либо существовавших в музыке, - джаза.

Краткий экскурс в историю создания саксофона подтверждает, на наш взгляд, тот факт, что изначально инструмент был создан для классического репертуара и классических жанров, несмотря на то, что популярность инструменту принес жанр джаза. Вероятно, в силу исконно европейского происхождения, саксофон в настоящее время активно используется в рамках классических жанров по всей Европе.
Необходимо отметить, что с момента своего изобретения в 1846 году, саксофон эволюционировал в различные версии: сопрано, джаз и контрабас саксофоны. Такие модификации саксофона, как правило, сделаны из латуни, а звуки воспроизводятся, когда игрок нажимает пальцем на октавы и другие клавиши. Современную популярность саксофона можно объяснить тем, что его можно использовать для воспроизведения музыки разных жанров. Например, студенты, которые предпочитают такие жанры, как джаз, поп, «R \& B», регги, рок или блюз и др., могут научиться играть свои любимые композиции именно на саксофоне.

Необходимо отметить, что европейская система обучения игре на саксофоне в настоящее время хорошо адаптирована для самых различных форматов преподавания, в том числе и онлайн-курсов. Многие музыкальные учебные заведения в Европе активно предоставляют возможность обучения с помощью различных моделей e-learning. Такой подход способствует тому, что изучение основ игры на саксофоне теперь стало доступным, в том числе - для начинающих. Необходимо отметить, что в европейских моделях обучения игре на саксофоне особое внимание уделено именно проблеме обучения начинающих музыкантов. С этих позиций европейские музыкальные образовательные учреждения предоставляют множество разных курсов для начинающих, которые были созданы музыкантами-теоретиками и легендарными саксофонистами. Эти методики, на наш взгляд, полностью адаптированы для всех категорий обучающихся. Например, студенты, участвующие в любом из онлайн-курсов, могут научиться играть на саксофоне в качестве хобби, при подготовке к музыкальному экзамену, прослушиванию музыки или присоединению к музыкальной группе.

Анализ научной и учебной музыкальной литературы позволяет говорить о трех основных моделях обучения игре на саксофоне, наиболее распространенных в европейских музыкальных образовательных учреждениях. Первая модель, британская, была разработана саксофонистами-педагогами в Королевском музыкальном колледже (Лондон) [11]. Базовый курс обучения игре на саксофоне включает в себя оптимальное сочетание уроков теории музыки, упражнений и композиций для практики, чтобы помочь студентам улучшить технику игры. В период обучения студенты знакомятся с правильными методами аппликатуры и способами поддержания хорошего ритма дыхания во время игры на музыкальном инструменте. На начальном этапе обучения преподаватели, как правило, объясняют, как выбрать подходящий мундштук, положение рук и предлагают изучение устройства язычков. Затем, на втором этапе обучения, студенты узнают, как разработать свой собственный репертуар, а также знакомятся с возможностями импровизации на саксофоне [10, с.22]. Теория музыки, включенная в кур- 
сы данной модели обучения, помогает начинающим понимать процесс чтения музыки. В этой области студенты знакомятся с основными и второстепенными триадами, доминирующими и уменьшенными аккордами и расширенными триадами [10, с.23]. Есть также специальные программы обучения, предназначенные для того, чтобы помочь студентам в совершенствовании и практической тренировке слуха, что позволяет лучше понять ключи и правильно набирать ноты во время практики.

В целом, для британской модели обучения игре на саксофоне характерны короткие и узкотематические занятия. Например, в музыкальном колледже Беркли практикуются занятия, посвященные тому, как правильно играть на саксофоне из положения стоя или сидя. Такие занятия, в частности, характерны для методики обучения, созданной Э. Мариенталем - профессиональным джазовым саксофонистом и лауреатом премии Грэмми. Будучи выпускником музыкального колледжа Беркли, Э. Мариенталь представляет полный мастер-класс по саксофону в том числе в формате онлайн-занятий [10, с.87].

Вторая модель обучения игре на саксофоне получила широкое распространение во Франции и представлена в программах Парижской национальной консерватории [4]. Следует отметить, что для французской школы игры на саксофоне характерны отдельные учебные программы для разных видов инструмента: альт-саксофон, тенор-саксофон, классический саксофон и др. Структура обучения представляет собой еженедельные уроки, которые длятся от тридцати минут до полутора часов. Во время учебного курса студенты знакомятся с методами игры на саксофоне в качестве ведущего инструмента в музыкальной группе [10, с.74]. Французская школа игры на саксофоне активно использует мультимедийные средства в педагогическом процессе: обучающие видео по методам сольной импровизации с саксофоном; реальные и анимированные видеозаписи, которые делают процесс обучения интересным и достаточно доступным даже для начинающих музыкантов. Особенностью французской модели обучения игры на саксофоне является то, что в большинстве учебных курсов каждая тема рассматривается в рамках отдельного занятия. Такой подход, по мнению французских педагогов-музыкантов, помогает студентам понять целостную концепцию игры, прежде чем перейти к следующему уровню обучения [9, с.102]. Занятия по теории музыки в такой учебной программе охватывают множество областей, которые помогают студентам развить хорошую основу в качестве новых саксофонистов. Области теории музыки, охватываемые этим курсом, включают в себя изучение гамм, различных аккордов, мелодии, развитие ритма и гармонии. Основная задача таких учебных программ - научить студентов импровизировать с саксофоном для сольных выступлений.
Третья модель обучения игре на саксофоне представлена в Дрезденской Высшей школе музыки им. Карла Марии фон Вебера и воплощена в исполнительском искусстве музыкантов Национального джазового оркестра Германии [7]. Для данной модели обучения игре на саксофоне характерен пошаговый подход, а занятия проводятся как на немецком, так и на английском языке, охватывая теорию музыки и практические занятия для студентов. Интересно отметить, что в рамках учебных программ немецкой модели обучения студенты изучают первые четыре ступени игры не только на классических, но и на джазовых саксофонах. Практические упражнения, которые следуют за каждым теоретическим занятием, направлены на совершенствование исполнительских навыков студентов. Если в британской и французской школах первой изучается теория, а затем - практика, то для немецкой модели обучения характерно поэтапное (пошаговое) чередование теоретических и практических занятий.

Помимо национальных европейских школ обучения игре на саксофоне, опят Европы богат международными учебными мероприятиями, связанными с игрой на саксофоне. Например, начиная с 2014 года, когда в Испании прошел международный конкурс саксофонистов, каждые три года проходит Европейский конгресс саксофонов (в 2020 году Конгресс должен был пройти в Италии, в городе Тренто, с 13 по 18 июля). Программа Конгресса включает в себя широкий спектр учебных и практических мероприятий: мастер-классы, конференции, выставки и концерты. Фактически, 6-дневный конгресс является отличной возможностью узнать все о саксофоне. Выдающиеся международные саксофонисты, ансамбли и саксофонные оркестры участвуют в мероприятиях конгресса. Интересно отметить, что в рамках данного мероприятия представлены как классические, так и современные репертуары, в том числе - джаз, этническая музыка и т.д.

По мнению европейских музыкантов и педагогов, именно такие возможности обмена опытом среди саксофонистов представляют собой важнейшее требование конкурентоспособности молодых музыкантов [5]. Поэтому с 1970 года в мире проводятся Всемирные конгрессы и Европейские конгрессы саксофонистов. В частности, III Европейский конгресс «Евро-сакс 2020» должен был проводится после крупных международных мероприятий, таких, как X Всемирный конгресс по саксофону, который состоялся в Италии 1992 году. В этом мероприятии, организованном ASI - Итальянской ассоциацией саксофонистов, приняли участие более 550 саксофонистов из 21 страны мира. Необходимо отметить, что в рамках Конгресса проводятся концерты с программой, включающей основные сольные концерты для саксофона и симфонического оркестра, а также для саксофона и духового оркестра, а также мастер-классы с участием 
великих мастеров.

Таким образом, можно сделать вывод о том, что для всех моделей обучения игре на саксофоне в европейских странах характерны общие концептуальные цели:

1. продвижение саксофона во всех его аспектах;

2. продвижение культурного, музыкального и образовательного сотрудничества;

3. продвижение репертуара благодаря исполнению новых методик, написанных в рамках учебных программ;

4. продвижение международного обмена педагогическим опытом через мастер-классы и конферен- ции;

5. продвижение теоретических и практических исследований благодаря историческому, музыковедческому и педагогическому вкладу национальных европейских школ.

Таким образом, несмотря на то, что в России сложилась собственная педагогическая система обучения игре на саксофоне, европейских опыт может быть особенно ценным для более эффективного взаимодействия российских педагогов с международным сообществом саксофонистов.

\section{ЛИТЕРАТУРА}

1. Друтин Л.Б. Проблема преемственности обучения игре на саксофоне в системе «школа - колледж» // MHK0. 2016. №6 (61). URL: https://cyberleninka.ru/ article/n/problema-preemstvennosti-obucheniya-igre-na-saksofone-v-sisteme-shkola-kolledzh (дата обращения: 28.05.2020).

2. Понькина А.М. Исполнительство на саксофоне конца XX века: характерные особенности эволюции // Вестник Адыгейского государственного университета. Серия 2: Филология и искусствоведение. 2018. №1 (212). URL: https://cyberleninka.ru/article/n/ispolnitelstvo-na-saksofone-kontsa-hh-veka-harakternyeosobennosti-evolyutsii (дата обращения: 28.05.2020).

3. Понькина А.М. Основные тенденции эволюции саксофонного исполнительского искусства 50-х - 60-х годов ХХ века // Культурная жизнь Юга России. 2018. №1. URL: https://cyberleninka.ru/article/n/osnovnye-tendentsii-evolyutsii-saksofonnogo-ispolnitelskogo-iskusstva-50-h-60-h-godov-hh-veka (дата 06ращения: 28.05.2020).

4. Conservatoire de Paris. Official site. URL: http://www.conservatoiredeparis.fr/accueil/

5. Eurosax-2020. URL: http://www.eursax20.eu/en/page/eurosax-2020

6. Garrett E.I Saw Stars in the 40's and 50's. 2nd edition. Trafford Publishing, 2015. 242 p.

7. Hochschule für Musik Carl Maria von Weber in Dresden. URL: https://www.hfmdd.de/

8. Ingham R., Cross J. The Cambridge Companion to the Saxophone. 3d edition. Cambridge University Press. 2015. - 226 p.

9. Martin H., Waters K. Jazz: The First 100 Years, Non-Media Edition. Cengage Learning. 2015. - 448 p.

10. Rebbeck L.A Practical Guide for Teaching the Saxophone to Beginners. FriesenPress. 2019. - 169 p.

11. Royal College of Music. Official site. URL: https://www.rcm.ac.uk/

() Цзян Вэньцзэ (68789265@qq.com). 